\title{
ATM Gene Mutation
}

National Cancer Institute

\section{Source}

National Cancer Institute. ATM Gene Mutation. NCI Thesaurus. Code C40459.

A change in the nucleotide sequence of the ATM gene. 